J O U R A L O F

French and Francophone Philosophy
REV VUE DE LA

philosophie française et de langue française

\title{
Between Earth and Sky
}

\author{
Jean-Paul Martinon
}

Journal of French and Francophone Philosophy - Revue de la philosophie française et de langue française, Vol XXIV, No 1 (2016) 25-44.

\author{
Vol XXIV, No 1 (2016) \\ ISSN 1936-6280 (print) \\ ISSN 2155-1162 (online) \\ DOI $10.5195 /$ jffp. 2016.756 \\ www.jffp.org
}

\section{(c)) EY-NC-ND}

This work is licensed under a Creative Commons Attribution-Noncommercial-No Derivative Works 3.0 United States License.

\section{ULIS D-Sunt}

This journal is operated by the University Library System of the University of Pittsburgh as part of its D-Scribe Digital Publishing Program, and is co-sponsored by the University of Pittsburgh Press 


\section{Between Earth and Sky}

Jean-Paul Martinon

Goldsmiths College, University of London

\section{Introduction}

Africa. Who are you?

I deliberately don't say here, "What are you?" As we know, the interrogative pronoun "what" is an attempt to grab the essence of something. As Heidegger says: "whatness [Wassein], comprises what one commonly calls... the idea or mental representation by means of which we propose to... grasp what a thing is." 1 As such, questions starting with the interrogative pronoun "what" are eminently violent because they reduce the object of inquiry to a thing that can be held in one's hand; that can make sense as a totality; that can be conceptualized with one idea. The history of philosophy - from Plato ${ }^{2}$ to Augustine, ${ }^{3}$ from Descartes ${ }^{4}$ to Lenin, ${ }^{5}$ all the way to Kwame Nkrumah, ${ }^{6}$ for example-is littered with the question "What...?"; with these violent attempts at grabbing the essence of something. ${ }^{7}$ Africa's history is also littered with these attempts at reducing a continent to an essence or concept. These attempts are absurdly grandiose (pinning down "the idea" of Africa, for example ${ }^{8}$ ) and ridiculously small (analyzing the minutiae of life in a village, for example ${ }^{9}$ ). In all cases, they try to envision Africa as an object to be possessed by any means and I know that we can't carry on doing that.

So I repeat once more, Africa, who are you ${ }^{10}$ ? I realize that using the interrogative pronoun "who" for what is usually understood as a geographical landmass is rather odd. One does not ask a continent who they are. The reason I am asking "who" rather than "what" is because I want to evade a more specific problem. The problem is that the question "What?" usually hides a very conventional understanding of time, the singular time of the author. This problem is not unique to African Studies; it permeates most fields in the humanities and social sciences. However, I think it is most salient in the field of African Studies because Africa has so often been the object of anthropological and ethnological investigations, and that, as Johannes Fabian's famous book Time and the Other has taught us, these 
investigations always posit two times: the time of the ethnographer and the time of the object investigated, namely, here, Africa. ${ }^{11}$ In what follows, my aim is not to repeat Fabian's well-known argument, but to excavate this much more constitutive problem of the time of the ethnographer or of any other "grapher" (a philosopher, for example) who speaks or writes about Africa or African philosophy.

You could no doubt ask: does it matter? Why should we explore the time of the author asking the question "What?" Isn't what counts what the author says and not his or her apperception of time? This is why evading the interrogative pronoun "What?" is crucial. My argument is that asking the question "What?" (objectively ${ }^{12}$ or subjectively ${ }^{13}$ ) necessarily always posits the time of the author as abstract, intuited, and hidden. This hidden time is, of course, that of thought. It is not the present or a stand in for presence because thought exceeds the confines of the "here and now," dragging in the past (the reason for the question) and the future (the anticipation of an answer). It is a much more complex time that stretches out in all directions with the author's "I think" at its core. He or she is indeed always there, alone, in the fullness of this abstract and intuited time without needing justification to be able to ask: "What is there?" /"What am I?" The question "What?" not only objectifies and essentializes what is put under scrutiny, it also consolidates the thinking author in its hidden temporal confines. Why is this always the case? Why do scholarly writing so often hide under an abstract and intuited time and can there be another way of going about it?

You could also ask: but isn't my question "Who are you, Africa?" not also positing an abstract apperception of time? The answer is "no" because the interrogative pronoun "Who?" - unlike "What?" - necessarily calls for dialogue and therefore for at least two times: the other's and mine. "Who?" concerns not the fixing of the representation of a thing, but the possibility of an interlocutor who could potentially respond. As such, the question "Who?" is effectively a theological and not a philosophical question. It is addressed not only to the other, but also potentially to the radically Other (in most cases, God). ${ }^{14}$ The theological aspect of the question "Who?" is not intended to entirely discard the question "What?" or to call for a return to religious talk. The shift from philosophy to theology is an attempt, on the one hand, to insist on the importance of treating Africa as a subject and not as an object and on the other, to posit the possibility of another time, and therefore of another kind of conversation.

By evading the question "What?" and insisting on the theological question "Who?" instead, my aim is to question what I call the mono-logic that always structures all thoughts in the humanities and in what concerns us here African Studies. As its name implies, a mono-logic refers to a singular logic. ${ }^{15}$ This logic is the one that equates time in general with an "I think" asking the question "What?" In other words, a mono-logic equates time with the cogito and therefore with logos. ${ }^{16}$ This equation is as old as 
philosophy: 17 it can be found, for example, in Aristotle who famously says that, "it is impossible for there to be time if there is no mind..." 18 clearly emphasizing the equivalence of the two. Hegel also insists that "time is the same principle as the I = I of pure self-consciousness,"19 thus leaving time with no room to being anything else. Even the early Heidegger asserts authoritatively that: "time and the 'I think' are no longer opposed to one another as unlike and incompatible; they are the same." 20 These random examples do no mean that no philosopher ever attempted to debunk the hegemony of this stringent mono-logic. Emmanuel Levinas' attempt, for example, to re-inscribe the radically Other in the cogito's "I am"21 only displaces the problem without resolving it. The "fearful face- to-face that takes place without mediation" 22 that Levinas speaks off, clearly shatters the sealed aspect of the cogito, finally giving us a glimpse of a time ("hers" 23) that, at last, isn't "his." However, while it gives the radically Other the possibility of playing its part in the constitution of time, it still rests on an inter-subjective relation with the cogito playing a crucial part: the perfect equal of time. ${ }^{24}$

By focusing on the unflinching equation time $=$ cogito, my aim is neither to resurrect the cogito, like Slavoj Žižek ${ }^{25}$ nor to confirm its universality. I realize, for example, that there might not be such a thing as a cogito in Africa because many African languages evade the subject-verb-object structure of Germanic and Latin languages, including English. ${ }^{26}$ While this is true, it does not necessarily follow that the temporality of a self-positing subject asking the question of philosophy-however it is grammatically constructed-does not remain an abstract, intuited and hidden time. This does not universalize the cogito. This simply emphasizes the universality of this abstract, intuited, and hidden time as the most common understanding of time for a subject positing itself in language and asking: "What?" It is as if the entire history of thought has been authorized by the extraordinary right of the equation: abstract, intuited, and hidden time $=$ cogito. The question is therefore this: how is one to conceive an approach to time that is not entirely dictated by this mono-logic, this equation that monopolizes all scholarly endeavors?

The reason I think it is important to raise this question in the context of this conference/publication is because, for me, a mono-logical thought is, as Grant Farred asked us to reflect upon, the limit at which all thought on Africa begins and ends. Farred's question for this conference was indeed "Why not think/propose the limit? Why not make the limit a constitutive element when thinking Africa and African philosophy? What thinking might thinking the limit provoke, make possible, compel even?"27 My attempt, in what follows, is to say, firstly, that all thinking of the limit is necessarily mono-logical because in order to constitute or erase a limit, it is necessary to equate the "I think" who envisages this limit with an intuited abstract time detached from this very limit. And secondly, to ask in return: if 
this equation is true, then is it at all possible to think a type of limit that isn't mono-logical? This is not an attempt to dismiss Farred's formidable question. On the contrary, this is an attempt to be as faithful as possible to the question and say: without a new thinking of the time from which one asks questions, no new mode of thinking on the limits of Africa or its philosophy is possible and this new thinking starts from the premise of the question: Africa, who are you? A question that, unlike "What?", invites, as I will try to show, a radically new relationship to time.

A word of warning before I begin: this is only a personal philosophical reflection. I am neither an Africanist nor a specialist in African philosophy or history. My knowledge of Africa is limited to the great lake region and specific African thinkers more or less within a Francophone remit. As such, my specialization is quite narrow. In this way, what follows restricts itself to a number of traditions taken from a small part of the continent and not from its many and diverse diasporas. Furthermore, although this essay starts with a wildly ambitious and generic first question about Africa, it does not pretend to situate itself within the context of African philosophy or to speak on behalf of African philosophers. This essay is effectively written as the continuation of a thought on time I began over fifteen years ago with my first book on the idea of the future outside of all predictions, and that I continued with two further publications, the one on Rwanda and the one on the spatial and temporal dimension of masculinity, The End of Man. ${ }^{28}$ This reflection has reached a new stage, one which, as I hope I will demonstrate, prevents the possibility of thinking time from a mono-logical perspective. This personal stage coincides with another text, which should ideally be read in parallel with this paper, called "Time Unshackled" for the journal New Formations (forthcoming, 2016).

\section{Poly-Logics}

There is perhaps one way of conceiving an approach to time that is not entirely dictated by a mono-logic and therefore by the equation cogito $=$ time. This approach is discretely put forward by two totally unrelated African philosophers: the late Rwandan Octave Ugirashebuja ${ }^{29}$ and the Ivorian Bourahima Ouattara. I will only focus on the latter for two reasons: firstly, for lack of space and secondly because Ouattara's argument situates itself in a much larger reflection on the conditions of possibility for thought at the pale of philosophy. There is unfortunately no space here for me to present Bourahima Ouattara, let alone do justice to his remarkable work. ${ }^{30}$ I have dedicated an essay to his work in a special issue edited by Pierre-Philippe Fraiture for the International Journal of Francophone Studies and I cannot therefore replicate here the arguments put forward in it. ${ }^{31}$ I will, however, highlight the following crucial aspects of his work in what concerns me here: the overcoming of the equation time $=$ cogito and mono-logical thinking. 
Bourahima Ouattara is a prolific philosopher who has already written seven books of philosophy, a novel, and a number of essays in the field of literary criticism. ${ }^{32}$ In what concerns me here, one of the most striking aspects of his work is that he always writes at the juncture between philosophy and ethnography. This juncture does not concern itself with disciplines or rigid institutional discourses. His aim is to devise a type of thought that is both truthful to his being and, if possible, free of concepts. To devise this type of thought, he comes up with what he calls an ethnothought, which should obviously not be confused with an ethnophilosophy. ${ }^{33}$ Contrary to an ethnophilosophy which necessarily takes the premise of Western and therefore Greek philosophy for granted, an ethno-thought starts from the premise of the death of philosophy and from the birth of one's own ethnos, which does not refer to one's own family, tribe, nation, or racial affiliation, but to the way, one apprehends oneself in timespace. In this way, Ouattara writes not at the intersection of rigid disciplines, but at a crossroad of practices, right where and when language articulates his world and allows him to depart from it. ${ }^{34}$

In an essay on the ethnological aspects of African ontology published in 2000 for the Cahiers d'études africaines, Ouattara confirms John Mbiti's view ${ }^{35}$ that African thought largely evades metric or measured representations of time. ${ }^{36}$ However, unlike Mbiti, his aim is not to support old or dubious ethnographic findings or to excavate some imaginary pre-colonial interpretation of being in relation to time. His aim is to devise a type of thought that would be representative of Africa in as much as its temporal structures evade all forms of measurements and therefore, as I will try to show, the equation cogito = time. He writes in a seemingly cryptic, but in fact formidable passage:

At the intersection of philosophy and ethnology, it is necessary not only to disarticulate chronological time, but also to de-center space in order to reveal its originary ontological coordination. This coordination shows that space is always the place of a dwelling that allows gods to visit mortals. This dwelling does not allow for any form of scientific archeo-logy that would be made with instrumental or utilitarian aims in sight. It calls instead for an ontological letting-be of four elements (gods/sky/earth/mortals). This does not put forward the kind of atomism that can be found in mechanical materialist thought. This work of disarticulation, on the contrary, invigorates and deepens the aims of an ethnology based on a post-philosophical thought. ${ }^{37}$

What is one to make of this statement? There is no doubt that Ouattara is largely influenced by the thought of Heidegger from after the turning (die Kehre). ${ }^{38}$ References to concepts such as "dwelling," "letting-be," and 
"gods/sky/earth/mortals" will sound familiar to most Heideggerian scholars. ${ }^{39}$ However, these references should be understood within the context of his views on Africa. In a book called Penser l'Afrique suivi de l'Afrique "Fragmentée" Ouattara puts forward the idea of thinking Africa in its facticity, that is, in the way it creates and produces itself aside from all forms of conceptualization (colonial or post-colonial). ${ }^{40}$ For that, he needs to think what it means to expose a fact of existence without automatically staining "it" with concepts: subjectivities, identities, histories, geographies, political, social, ethnic, or cultural contexts, etc. ${ }^{41}$ This attempt to think at the edge of concepts does not mean that he blatantly ignores what makes Africa what it "is" or what constitutes the ontical realities of African's daily lives. His work of fiction clearly attests to that. ${ }^{42}$ His aim is on the contrary to think what structures the facticity that underlines his own ethnos: temporarily being a Heideggerian Ivorian philosopher living in Basel-with all the contradictions that this entails.

With this aim, Ouattara has no other choice, but to perceive himself at once within a post-philosophical order and therefore in a sphere where the question "what?" no longer has a strong hold. As such, his apperception of time-space ${ }^{43}$ necessarily takes place at the cusp of theology ("Who?") without entrenching this theology, as I will show, in any religiosity or spirituality. At this cusp, Ouattara articulates time-space, following Heidegger, as dwelling. ${ }^{44}$ Dwelling does not mean living in a house or in a region of earth and surrounding ourselves with familiar objects and call it home. Dwelling means initiating one's own nature, our being capable of death as death. In other words, dwelling means setting ourselves into our own presencing and, in the process, originate time-space. Now it would be wrong to imagine this dwelling as yet another hidden mono-logical point: the "dwelling fact" of existence structuring us behind the cumbersomeness of our lives, for example. Ouattara writes from the premise of the death of philosophy and therefore from the demise of all forms of ontologies, including the device known as Dasein. Hence the unusual reference to gods visiting mortals and the fourfold.

The reason Ouattara mentions the fourfold (with its gods) in passing is because in a post-philosophical context, dwelling cannot be the only dimension that structures time-space. Dwelling is only one dimension amongst four. Mortals dwell, but this undeniable fact is not the only thing that constitutes time-space. Alongside mortals setting themselves into their own presence, sky, earth, and gods also inhabit and create time-space. Together they form the fourfold. Together they create time-space. The aconceptuality of time-space thus become much more difficult to describe because it is no longer a mono-logical affair structured by a lonesome hypostasis at its core: the cogito. It involves other dimensions that come to disturb this mono-logic. This is not an easy thought because with the fourfold, it is necessary to think time-space as the combination of more than 
two dimensions crisscrossing each other without a singular perspective (the "I think" / I am") looking back and forth, ahead and behind.

Consequently, this fourfold should not be understood as a set of cardinal points or anything that could stand for a spatial or geographical metaphor. Let's take the first two in Ouattara's reference by going back to Heidegger words: "The Earth is the serving bearer... The sky is the vaulting path of the sun." 45 The earth is not the soil on planet earth, but that from which mortals dwell. In this way, the earth does not stand for the continent called "Africa" or "Europe," for example. The earth stands for the serving bearer that gives us the "idea of Africa." This serving bearer can be anything associated with that name: from a clay object to an economic statistic, basically, anything from which to cultivate ideas or concepts while mortals set themselves into presencing. By contrast, the sky stands for everything into which mortals dwell. This refers neither the atmosphere nor the outer space seen from earth, but the space mortals give to what they have taken from earth. The sky stands for what mortals make of the earth, what they project themselves into, what they cast light onto, what they illuminate with meaning. 46 The sky is therefore the space into which "the idea of Africa" acquires meaning, whether laboring the earth or writing about it. Overall, it is under the sky and on earth that mortals dwell, that is, it is there, in between the two, ${ }^{47}$ that they initiate their own nature - their being capable of death as death.

Inevitably, the big question is why on earth and under the sky should there be gods visiting mortals? Why gods and not God? This is the trickiest of references because it is so loaded with spiritual, mystical, religious and metaphysical connotations. Gods in both Ouattara and Heidegger's minds have nothing to do with any religious expression or representation, not even those who deny all forms of representations as in Islam. 48 The word "gods" in the plural does not refer to a deity in the conventional sense of the term. As one dimension of the fourfold, the gods stand for the manifold 49 emergence of what is unexpected or unusual in mortals' living present. ${ }^{50}$ As futurities, the gods alter mortals' access to presence, by bringing in what is new and as such can never be described as something "pre-given." 51 As Reiner Schürmann rightly says, they designate "the sudden irruption in which a constellation of presence and absence situates everything anew." 52 In this way, they do not stand for the infinite, the radically other, the almighty, the creator, the star-maker, the holy ghost or any other entity, not even Spirit, this intertwinement of human and divine agency as in Hegel. Nothing can characterize them because through their disruptions, they come with the Word, as the fourfold emerges and this, without any promises of redemption or salvation and without any eschatological or messianic signs.

In this way, there can be nothing tralatitious about these gods simply because they can never perdure over time and in doing so create religions or spiritual movements. There is no "moment" when suddenly the Word 
appears, God speaks, and then "another moment" when His Word needs to be repeated because with the gods, there is no distinction between the Verb, 53 its advent, or its repetition. In other words, there isn't first the Word and then the possibility of semantic conflict, wars and genocides. There is the happenstance of the fourfold which is nothing other than the event of the Word and therefore of war, right when it takes place and right when peace is concluded. ${ }^{54}$ In this way, the gods have no moral compass, and they come with no Torah, Bible, or Koran. They work only to disrupt unexpectedly the fourfold and mortals need to deal with these disruptions, not on their own, but as part of the fourfold, alongside earth and sky. ${ }^{55}$ The gods-another difficult thought-effectively manifest themselves in the dependency of the fourfold, that is, in the dependency of mortals, sky and earth. There would be no gods without the fourfold, that is, without the emergence of the Word, any event whatsoever.56 This mutual independency within the fourfold is crucial: we get the surprises that the fourfold deserves, including tsunamis and wars. ${ }^{57}$

With this passing reference, Ouattara points at the possibility of finally getting ourselves out of the strict equation time $=$ cogito that has plagued philosophy since immemorial times. With the fourfold, we leave behind the narrow confines of our relationship with time-space and accede to a fourfold spatio-temporal order in which neither "I think" nor "I am" is central. Downgraded (and not discarded, as in Quentin Meillassoux, for example ${ }^{58}$ ) from its imperious position, the cogito suddenly needs to accommodate itself with the "whereunto" and the "why" of the other folds: earth, sky, and gods. The gods are neither the cause nor the end of mortals' happenstance, and yet they cannot take place without them. Inversely, we, as mortals, are neither the creators nor the inventors of gods and yet we cannot dwell without them. Earth and sky render vain all our attempts at elevation and yet we would not elevate ourselves without them. The poly-logic inherent in the fourfold dislocates, as Ouattara says, our long-held ontical interpretations of time-space, forcing us to accept that the mono-logic under which we operate is nothing but one of four that arises non-simultaneously, the uniqueness of the event of being, the factuality of history in which man plays, but only a small part.59 By quadrupling the poles of reference, Ouattara, in the wake of Heidegger, ends up debunking all foundations and principles and the entire arsenal of archic and telic spatial and temporal representations. With this discrete hint of the fourfold in a text on African ethnologies, Ouattara basically manages to remove time-space from our commonplace mono-logic epochal stamping and hands it over to a poly-logic situation in which the cogito is, at last, no longer the sole player.

Now it would be wrong to imagine Ouattara's interpretation of timespace as if following some twisted or perverted logic: applying hyperabstract ideas borrowed from an elderly ex-Nazi-sympathizer onto his own being and by extension, African thought. In a way, one could argue that 
nothing could be further from anything relating to Africa. But Ouattara's aim is neither to pitch one institution against another (Greek/African philosophy) nor to invent some tenuous link between the ethnographies and philosophies of the Ivory Coast and those of Germany. His aim is to think "the philosophical-ethnological status of thought," 60 that is, a type of thought that is finally unencumbered by the gravitational forces of monology, forces that always bring everything down to the subject understood as object stuck in a single time with $a$ past and $a$ future. This is a difficult thought because it does not allow one to dwell on any folkloric aspect of our own ethnos, i.e. the idiosyncrasies of the places and/or times from which we hail. The aim is to think the happenstance of our Be-ing at its place of dwelling, that is, as it enters into presencing, as it deals with the fourfold with its unruly, but dependent gods.

To make such a bold claim is not to suggest that, from now on, we should return to polytheism and believe in gods or that we should try to reinvent faith in the hope of finding where gods are lurking. Whether monotheist or polytheist, to "believe" or "seek out" is to posit the divine or divinities as existing independently of mortals. But this is not the case with either Ouattara or Heidegger. Gods and mortals are united in their codependency between earth and sky. In this way, if we follow Ouattara's thought, then the aim is therefore two-fold: on the one hand, we can no longer think in one time only: the cogito needs to deal with more than just the time that structures it; it needs to deal with other dimensions, some of which are out of its control or jurisdiction. On the other hand, this thought allows us to see that the only way out of the constitutive problem we face everyday in our capitalist world - the fact that the present is never present enough, a problem that contemporary philosophy is at the moment unable to overcome ${ }^{61}$ - can only be resolved by radically multiplying and increasing the depths that we give to the future, here named gods. ${ }^{2}$ The gods are futurities, here understood not as a singular horizon of possibility, but as a firmament of untimeliness, the very tangible marks of what can never be guessed, what can never give us a return in this life. Isn't this precisely what capitalism abhors above all else?

\section{Africa}

So here I am addressing myself to you, Africa. ${ }^{63}$ The "I" that addresses you and signs this essay counts for little.

Firstly, I do not stand high and mighty outside of the semantic economy of language, dictating the view from an imaginary site of eternal presence or from a universal "elsewhere" detached from the vagaries and idiosyncrasies of my mortal body. I have also avoided using an impersonal and passive voice in order to emphasize a supposed impartiality, objectivity, or detached subjectivity. My words engage the semantic economy of language from a 
specific place in time-space and from the peculiarities of an ever-changing body that knows it is dying, but this economy is not the only one that makes time-space. Another economy, a much more subtle and complex economy one that defies all economies as trade or bartering-also structures this language that is now, more than ever, never really mine. ${ }^{64}$ Earth, sky, and gods also play their part in this economy. The semantic economy of language would not exist without this continually disregarded fourfold economy that sunders its associated mono-logical time-space into a plurality of time-spaces.

Secondly, I do not stand as the agency through which time-space take place. My finitude isn't the only thing that can reveal and paradoxically also evade the in-finity ${ }^{65}$ of time-space. No capitalized word, in Greek or in any other language, embodies alone such event. Furthermore, my proper name does not hypostasize this event-even if conceived on the edge of property or properness ${ }^{66}$ - with a date of birth and an indeterminate date of death on the horizon, channeling on the way im-memorial pasts and un-foreseeable futures. Past and future are made up of other dimensions-earth, sky, gods - that exceed my finitude, including the future ephemeral engraving on my tombstone. In this way, my finitude is just one dimension of a fourfold whose other dimensions exceed me and point in the direction of a beyond "me," a divine "beyond" where I no longer matter, where none of this (African studies, philosophy, the world, the earth), no longer matters.

Once more, here I am addressing myself to you, Africa. The "you" of this address arises out of a depth without measure.

Firstly, this "you" or this "Africa" comes neither from a mysterious place of learning nor from direct observation. In other words, you neither stems from the hallowed spaces of libraries (SOAS in London, for example) nor from the intricacies of lived experienced (my colleagues in the University town of Butare in Rwanda, for example). You come from a place that paradoxically allows itself to be apprehended and exploited and yet exceeds all attempts to harness or master. You, Africa, rise before me from an impenetrable in-finity made up of questionable inventions, dubious ideas, dangerous parallels and analogies (pre-colonial, colonial, or postcolonial) and of a depth that defies all understanding of depth. The earth from which you hail, this earth that allows you to inspire and agitate us into action and writing, can only indeed shatter all scientific knowledge, past, present, and future, including the proceedings of this very scholarly undertaking. The earth is no substantial ground, but a withdrawal of ground. ${ }^{67}$ If this weren't the case, Africa would have never been able to rise in our consciousness in the way you do here.

Secondly, this "you" does not stem from a specific continent, not even the one that bears your name. While there is no doubt that, as Mudimbe says, "there are natural features, cultural characteristics, and, probably, 
values that contribute to the reality of Africa as a continent and its civilization as constituting a totality" 68 worth addressing, these features, characteristics, and values are not exactly what make you stand here before us. This earth, out of which you grew, was made by Grant Farred, Gerard Aching and Kasereka Kavwahirehi. No, they are not the fathers of Africa, but they are the ones who conjured up the ferment that allowed the addressee of this paper to rise up before us, mortals. Their efforts were not just practical, organizational, or developmental (stemming from the previous conference that took place at Rhodes University, for example). Their efforts exceed such simple causalities and effects. The "you" or the "Africa" that emerges here in these pages rose because of their mortal thinking bodies involved in other earths, skies and gods. Without their own fourfolds, without this unfathomable and diverse ferment out of which you grew, I could not have addressed you.

And again, here I am addressing myself to you, Africa. This "you" elevates itself beyond this aggregate of living subjectivities that makes Africa what it is.

Firstly, this "you" or this "Africa" does not elevate itself into an academic or scholarly setting, the kind of setting-spoken or written - in which scholars ponder the meaning of Africa, its limits or ends. This does not mean that there is no event called "you" or "African Thinking: And/At its Limits." This simply means that a lot more is at stake when it comes to the way this addressee manifests itself as Africa. Firstly, "you" is both singular (the second person singular, Africa) and plural (the second person plural, the many significations and/or manifestations attached to the word Africa). This undecided character necessarily sets this addressee or denomination apart, not into an "elsewhere," but at a limit where the semantic unity is unstable: at once singular and multiple. We all have both one strict idea of who you are and a multiplicity of conflicting opinions about you. As such, when addressed, this "you" or Africa elevates itself into a realm on the edge of all discursive formations whether oral or written; a realm for which the sky is the limit. And this limit is changeable, always prone to inhospitable weather. In this way, the sky into which "you" or Africa appears is therefore structured by much more than what we can think, do, or say, at conferences, in academic journals, or anywhere else on earth; a "much more" without which none of this could take place.

Secondly, this "you" or this "Africa" does not emerge as a fact or object obediently setting itself up to be probed, dissected, analyzed, and discarded. The very fact that you happen, that scholars address you, does not mean that you raise yourself solely to be placed, submissive and docile, under the scrutiny of scientific enquiries. Because you are above all, as previously mentioned, a subject or a plurality of subjects, you are effectively limit-less, a finite and yet infinite offering. This does not mean you are a gift created, produced, or manufactured for study, action, or entertainment. This means 
instead that, as subject(s), you are an offering that defies all forms of biological or logical creation, production, or manufacture. Insubordinate, rebellious, the other of the upright concept, 69 you are an offering that never ceases to frustrate anyone who approaches you. Your defiance knows no bounds. The ungraspable expanse of the sky into which you elevate yourself therefore also plays its part and mortals need to hear this unruly in-finity if they want to do right by you. Without the boundlessness of the sky into which you emerge for consideration, I-or anyone else-could not even begin to address you.

And finally, one last time, here I am addressing myself to you, Africa. In this sentence, the subject ("I"), the verb ("addressing") and the addressee ("you" or "Africa") don't just come together because of an "I think."

Firstly, the sentence "I am addressing myself to you, Africa" does not just constitute an event between mortals. It is not simply a response to a call for papers. If it were, then it would simply be discussed for a while-the time of a conference, the time of a peer-reviewed journal-and then discarded, the typical mortal destiny of all addresses, whether oral or written. To reduce this address to such an inevitable destiny-even if it is understood as destinerrance, i.e. an errancy outside the control of the addressor $^{70}$ - is to demote it to the status of object: a paper, an essay. To say "I am addressing myself to you" is in fact to create an event that also involves utterly dependent, but unfathomable gods. Again, mention of these gods does not intend to create a new religion, but to give figure to how the future manifests itself: in this case, your volatile responses, your unpredictable thinking or questioning, i.e. all these monstrous disruptions to the event of this address. In this way, it is not only in your hands that I am leaving this message; it is also in the hands of these unruly and yet dependent gods. Without these gods, without these responses that make who you are, this address would not have taken place.

Secondly, the event "I am addressing myself to you, Africa" is not just an ethical response to a problem of limits - the limits of African thought, for example. Strictly speaking, this address neither inscribes itself solely within a set of normative ethics (polite codes, scholarly etiquette, academic good conduct, contractual arrangements, etc.) nor within an understanding of ethics that involves the radically Other, a type of responsibility before all forms of morality. If this were the case, then this address would inscribe itself within the context of a tradable morality: either with society (an economic covenant) or with God (a religious or spiritual covenant). Because dependent gods are involved, this address sets itself instead in a plurality of responses that can never be pinned down with laws, codes, or precepts. The earth gives rise to it. The sky allows it to take place. Mortals give it significance. Gods disrupt it. This fourfold approach does not free the addressor of ethical or moral duties. The fourfold constrains him or her to think their ethical responses as one amongst other responses originating in 
other dimensions, including earth, sky, and gods. These other responses might not necessarily be ethical. Other dimensions' responses might well jeopardize all chances of lawfulness and salvation.

I started this paper with the improper question "Africa, who are you?" By asking the question "who" instead of "what" my aim was to question the recurrent mono-logic that always informs most scholarly addresses, including those put forward in African Studies and, more broadly, philosophy in general. Through such questioning, I hope to have shown that it is not quite possible to reduce either the "I think" and/or the "I am" to time as such. Other dimensions inflect and deflect, distort and reassemble this cogito without allowing it to either reconfigure it as the twin of time or merge it with time to the point of being utterly undifferentiated. This is what Ouattara's radical destabilization of time-space allowed us to see and put to the test. The present paper only hints at the possibilities of not making time and the "I think" / I I am" the sole organizing structure. Much more will need to be said and written in order to continue debunking this simple myth that time and the cogito are either one or unrelated.

Beyond the present figuration, Africa will obviously not respond. I have neither plundered the Colonial Library nor raided post-colonial theory in order to express a fictional or scholarly response. I have been economical in my use of African or Western philosophy in order to provide a more or less meaningful response to the conference/publication's call. But even through this use, I have also not imagined a dialogue between "you" and me. Like Ouattara, I have simply engaged with the question of this conference/publication in a way that reveals my ethno-thought. Again, this does not mean I engage either the science of ethnology or the discipline of philosophy. This simply means that I operated from a post-philosophical perspective that neither betrays my background nor makes assumptions about the other. This ethno-thought took place because earth, sky, and gods were also involved. Together, the fourfold rang. ${ }^{71}$ Out of this ringing, Africa made itself faintly heard in the distance, not as a sum of historical, geographical, cultural, or societal accounts that can be validated or verified, evaluated or even judged in any of the ontic sciences, but as potential subject(s) perverting all these ontical determinations and calculations.

This ringing hints at the fact that no thinking of a limit to Africa or African philosophy is possible. Free from the dictatorship of mono-logical referents, the limit ceases to be conceivable even as an invaginated 72 topology where the demarcation between an "over here" and an "over there" has been blurred to the point of being utterly unrecognizable. It also ceases to be conceivable as a provocation, the urgency of the call of that which is to come. Africa or African philosophy can have neither one limit nor a multiplicity of limits not because it can never be conceived as an object of representation, but because it knows no proper ground or enclosed sky and because no mortal is able to enunciate it without these gods that pervert 
the very consolidation of its happenstance. Thus freed, what we call a continent of earth, what we determine as having specific cultural and societal values and for good or bad, a few ethnological referents, can no longer gather into one. From now on, you or Africa can only disperse into a poly-logical fourfold doing for which mortals' letting-be ${ }^{73}$ is its absolute precondition. Indeed, without letting be of the "I think" / time (and thereby of all mono-logical thinking), we will not be able to hear ${ }^{74}$ how we dwell alongside earth, sky and gods. To hear the poly-logic of the fourfold, to hear how we dwell, we really need to start learning to be mortal and invent a new post-philosophical language.

${ }^{1}$ Martin Heidegger, On the Way to Language, trans. Peter D. Hertz (London: Harper Collins, 1971), 94.

2 Socrates, for example, asks: “what is the beautiful?" Plato, "Hippias Major," in Early Socratic Dialogues, trans. Emlyn-Jones Chris (London: Penguin Classics, 2005), 287d-e, 241.

${ }^{3}$ Augustine, for example, asks: "What then is time?" Saint Augustine, Bishop of Hippo, Confessions, Lib xi, Cap xiv, Sec 17, trans. Albert C. Outler (Mineola: Dover, 2002), 224.

${ }^{4}$ Descartes, for example, asks: “What is a man?” René Descartes, Meditations on First Philosophy, \# 25, trans. John Cottingham (Cambridge: Cambridge University Press, 1996), 17.

${ }^{5}$ Lenin, for example, asks: “What is to be done?” Vladimir Lenin, Essential Works of Lenin: “What Is to Be Done?” and Other Writings, trans. Henri Christmans (New York: Bantham Books, 1966), 53.

${ }^{6}$ See for example, the focus on "what there is" in Kwame Nkrumah, Consciencism: Philosophy and Ideology for De-Colonization (New York: Monthly Review Press, 1964), 6-8.

7 As Derrida says, "The question ["what is?"] has forged the whole history of the West and of Western philosophy, that is, nearly everything from Plato to Heidegger." Jacques Derrida interviewed by Roger-Pol Droit, “Qu'est-ce que la déconstruction," Cahiers du Monde 18572 (Tuesday 12 October 2004): 3.

${ }^{8}$ Like the various "ideas of Africa" put forward in the Colonial Library. See, of course, Valentin Y. Mudimbe, The Invention of Africa (Bloomington: Indiana University Press, 1988) and The Idea of Africa (Bloomington: Indiana University Press, 1994).

9 See, for example, Danielle de Lame, A Hill Among a Thousand, trans. Helen Arnold (Madison: The University of Wisconsin Press, 2005).

${ }^{10}$ As will become clear at the end of this essay, the "you" in this question should not be understood in a symmetrical sense, whereby the "you" would simply equate the "I." This "you" should be understood in an asymmetrical sense, that is, as a radical anteriority, height or depth. On this topic, see Emmanuel Levinas, Totality and Infinity, trans. Alphonso Lingis (Pittsburgh: Duquesne University Press, 1969), 75.

${ }^{11}$ As is well known, he calls this two-time, allochronism. Johannes Fabian, Time and the Other: How Anthropology Makes its Object (New York: Colombia University Press, 1983).

12 For an objective approach to the question "What is Africa?" see, for example, Achille Mbembe and Sarah Nuttall's special issue of Public Culture of 2004, in which neither the editors nor the 
contributors ask themselves: From what apperception of time do they ask the question about Africa? Objective analyses, like the self-conscious ones proposed by Mbembe and Nuttall are exemplary in the way they rest on a hidden temporal perspective. Achille Mbembe and Sarah Nuttall, "Writing the World from an African Metropolis," in Public Culture 16, no. 3 (Fall 2004): 347-372.

13 For a subjective approach to the question "What is Africa?" see, for example, Valentin Y. Mudimbe's attempt to put forward instead the question "What am I?" Even with such a subjective question, Mudimbe never asks himself: What conception of time allows him to put forward the question: “What am I" or, what time structures his "I think?" Valentin Y. Mudimbe, Parables and Fables: Exegesis, Textuality, and Politics in Central Africa (Madison: The University of Wisconsin Press, 1991), xxi.

14 On this topic, see Robert Gibbs, Correlations in Rosenzweig and Levinas (Princeton: Princeton University Press, 1994), 100-104.

${ }^{15}$ Although the etymology is the same, a mono-logic has obviously nothing to do with a monologue, at least not in the way it is understood in theatre, for example. The semantic shift that slowly occurred since Greek times from monó- as "single" to monó- as "alone" would necessitate a lengthy philological analysis that unfortunately cannot take place here.

16 Jacques Derrida was the first to note this strange equation, but without exploring it in detail, preferring instead to focus on the semantic instability of all philosophical discourses on the origin of time. In what follows, my aim is not to look again for the origins of this equation in the history of philosophy, but to highlight its common occurrence and to put forward the possibility of another approach. See Jacques Derrida, "Ousia et Gramme: Note on a Note from Being and Time," in Margins of Philosophy, trans. Alan Bass (Chicago: University of Chicago, 1982), 44-5.

17 For a comprehensive historical overview of this question, albeit with only a tangential focus on the cogito, see J.J.A. Mooij, Time and Mind: The History of a Philosophical Problem (Leiden: Brill, 2005).

${ }^{18}$ Aristotle, Physics, trans. Robin Waterfield (Oxford: Oxford University Press, 1996), 223a21, 115.

19 G.W.H. Hegel, Phenomenology of Nature, trans. A.V. Miller (Oxford: Oxford University Press, 1970), § 258, 35.

20 Martin Heidegger, Kant and the Problem of Metaphysics, trans. Richard Taft (Bloomington: Indiana University Press, 1997), Section 34, § 191-2, 134.

21 See Emmanuel Levinas, Otherwise than Being or Beyond Essence, trans. Alphonso Lingis (Pittsburgh: Duquesne University Press, 2004), 80.

22 Emmanuel Levinas, Existence and Existents, trans. Alphonso Lingis (Pittsburgh: Duquesne University Press, 2001), 95.

${ }^{23}$ For a remarkable commentary on Levinas' understanding of the femininity of the radically other, see Catherine Chalier, Figures du Feminin (Paris: Antoinette Fouque, 2006).

${ }^{24}$ For this reason, Levinas never admits that if the Other is indeed inscribed in the "I am" then this "I am" must also be, to some extent, absolutely an-archic and if it is so, then, on all accounts, it must also be gibberish, the Other of reason and logos. But Levinas never admits this. For him, the cogito always maintains itself on the edge of madness, unreason, and senselessness. It is this edge that secures it within an inalienable mono-logic. 
${ }^{25}$ From Slavoj Žižek, ed., Cogito and the Unconscious (Durham: Duke University Press Books, 1998) to Slavoj Žižek, The Parallax View (Cambridge: The MIT Press, 2009).

${ }^{26}$ On the fact that the cogito is not African, see Alexis Kagame, "Aperception empirique du temps et conception de l'histoire dans la pensée bantoue," in Les Cultures et le temps: au carrefour des cultures; études préparées pour l'UNESCO, Paul Ricoeur, ed. (Paris: Payot, 1975), 4; John S. Mbiti, African Religions and Philosophy (Johannesburg: Heinemann, 1990), 199-22 and 209; and finally, Kwasi Wiredu, Cultural Universals and Particulars: An African Perspective (Bloomington: Indiana University Press, 1996), 140-1. For an analysis of the cogito in Africa, see Ernest Menyomo, Descartes et les Africains (Paris: L'Harmattan, 2010).

${ }^{27}$ Email correspondence dated 17 September 2014.

${ }^{28}$ See Jean-Paul Martinon, On Futurity: Malabou, Nancy, and Derrida (London: Palgrave Macmillan, 2007) and The End of Man (New York: Punctum Books, 2013).

29 Octave Ugirashebuja was a Rwandese philosopher and Jesuit priest (1938-2012). His reflections on an alternative to the mono-logic of time-space can be found in his PhD on Heidegger's work, published in 1977. In this work, Ugirashebuja develops a profound reflection on how to live "poetically" in a Heideggerian sense, a topic that, although close to the one developed in this essay, cannot unfortunately be addressed here. See, Octave Ugirashebuja, Dialogue entre la poésie et la pensée d'après l'oeuvre de Heidegger (Brussels: Editions Lumen Vitae, 1977).

30 In a nutshell, Ouattara was born in 1962. He studied philosophy at the University of Montpellier (France) and in 1996 obtained his first doctorate from L'Ecole des Hautes Etudes en Sciences Sociales, Paris. He is now Professor of Philosophy at the University of Basel. He is currently finishing a new novel and putting the finishing touches on his second $\mathrm{PhD}$ on the limits of democracy for the Institut d'Etudes politiques, Grenoble.

${ }^{31}$ See Jean-Paul Martinon, "The Equivocal Concept: The Work of Bourahima Ouattara," in The International Journal of Francophone Studies 18, no. 2-3, edited by Pierre-Philippe Fraiture (2015): 339-357.

32 Besides the works mentioned in this essay, see also: Adorno et Heidegger: une controverse philosophique (Paris: L'Harmattan, 1999); Adorno: Philosophie et Ethique (Paris: L'Harmattan, 1999); "Ontologie de la pauvreté chez Heidegger," in Divinatio 13 (Spring-Summer 2001): 151 162; Adorno, une éthique de la souffrance (Paris: L'Harmattan, 2004); Senghor, lecteur de Barrès (Paris: L'Harmattan, 2014); Patrice Lumumba, une iconographie politique (forthcoming); Figures de la haine de soi dans le roman négro-africain francophone (forthcoming).

33 Bourahima Ouattara, "Figures ethnologiques de la pensée de l'être," in Cahiers d'études africaines 157, (1999): 90.

${ }^{34}$ As he says: "What I call the ethnological figures of the thought of Being corresponds to the end of philosophy as the site of a new beginning." Ouattara, "Figures ethnologiques de la pensée de l'être," 81, my translation.

${ }^{35}$ Mbiti, African Religion and Philosophy, 24.

36 Ouattara, "Figures ethnologiques de la pensée de l'être," 89-90. In what follows, I only take from this essay-with some violence, I admit-what I need to make my argument. A much longer analysis would be needed to explore Ouattara's complex reading of Africa and ethno-thought. I can only leave this for another time. 
37 Ouattara, "Figures ethnologiques de la pensée de l'être," 85. In this translation, I deliberately omitted the word "mythological" in order to emphasize the potential of this sentence outside of Heidegger's quasi-mystical thought, which Ouattara embraces without justification or explanation. In doing so, I follow Levinas' argument that when it comes to Heidegger, it is always necessary to distance oneself from the atmosphere of his work. For a further justification for this deletion, see Martinon, "The Equivocal Concept." For the necessity of leaving Heidegger's thought, see Emmanuel Levinas, Time and the Other, trans. Richard A. Cohen (Pittsburgh: Duquesne University Press, 1987), 45.

38 Ouattara is not the only African philosopher who attempts to think the work of Martin Heidegger in relation to Africa. For a comprehensive analysis of this field of study, see, Antoine-Dover Osongo-Lukadi, Heidegger et l'Afrique (Louvain-la-Neuve: Editions Academia, 2002), especially, 66-8.

${ }^{39}$ For an account of Heidegger's fourfold, see amongst others: Andrew J. Mitchell, 'The Fourfold,' in Bret W. Davis, Heidegger: Key Concepts (London: Acumen, 2010), 208-18.

40 See Bourahima Ouattara, Penser l'Afrique suivi de l'Afrique "fragmentée" (Paris: L'Harmattan, 2001).

41 As this essay will show, this is what distinguishes Ouattara from Heidegger. While the latter wallows in peasant Germanic-Neo-Greek references, the former, aware of the debates on ethnophilosophy and the fast changing face of globalization, develops an ethnos free of all folkloric referents, i.e. a situatedness in a culture without putatively stable referents. See Ouattara's many analyses of Heidegger's work.

42 Bourahima Ouattara, Le Cimetière Sénégalais (Paris: L’Harmattan, 2006). In this novel, Ouattara tells the story of Djibril, an African immigrant encountering the prejudices of a provincial French town.

43 The use of the expression "time-space" does not refer to the space/time of physicists or to any form of mathematical calculation. In Ouattara's work, the expression "time-space" refers to Heidegger's Zeitraum, i.e. to a "making present" that takes place without giving priority to either time or space. See Martin Heidegger, "Zeit-Raum" in On Time and Being, trans. Joan Stambaugh (New York: Harper, 1972), 14.

44 For the sources of Ouattara's understanding of "dwelling," see Martin Heidegger, "Building Dwelling Thinking," in Poetry, Language, Thought, trans. Albert Hofstadter (New York: Harper \& Row, 1975), 141-160.

45 Heidegger, “Building, Dwelling, Thinking," 147-8. Note that Heidegger references here Plato's view that the sun provides living beings with "creation, growth and nourishment." As such, the sun's light is at the start of all human endeavors. Plato, Republic, trans. Francis Cornford (London: Penguin, 1941), 508a-509b, 220. For the dangers of overemphasizing light/sun, see Derrida, "The Violence of Light," in Writing and Difference, 105-8.

${ }^{46}$ On this topic, see Reiner Schürmann, Heidegger on Being and Acting: From Principles to Anarchy (Bloomington: Indiana University Press, 1990), fn. 158, 348.

47 See Martin Heidegger, “Hölderlin's Earth and Heaven," in Elucidations of Hölderlin's Poetry, trans. Keith Hoeller (Amherst, Humanity Books, 2000), 186.

48 There is no space here to expose the origins of Heidegger's interpretation of these gods (his reading of Hölderlin) or to explain these gods after the death of God. With regards to Hölderlin, see: See Jean-François Mattéi, Heidegger et Hölderlin: Le Quadriparti (Paris: Presses 
Universitaires de France, 2001). With regards to the death of God, see Frank Darwiche, Heidegger, Le Divin et le Quadriparti (Nice: Les Editions Ovadia, 2013).

49 The plurality of this futurity is crucial because it allows us to evade the mono-logicality of, for example, Derrida's Judeo-atheist monotheism, for example: "The Messiah, the thinker of the dangerous 'perhaps,' the god, whoever would come in the form of the event-that is, in the form of the exception and the unique." Jacques Derrida, Politics of Friendship, trans. George Collins, (London: Verso, 2005), 174. On this Judeo-atheist monotheism, see, amongst others, John Caputo, The Prayers and Tears of Jacques Derrida (Bloomington: Indiana University Press, 1997).

${ }^{50}$ Heidegger says that the impetus behind these movements comes from the godhead (die Gottheit), the realm of divinity. Heidegger, 'The Thing,' in Poetry, Language, Thought, 146-7 and 178. For a commentary on this, see Martinon, "Time Unshackled." Briefly, this godhead stands not for God as such, but for the future understood in its radicality: i.e. what cannot be anticipated or predicted and yet can only manifest itself through gods as future-presents. Understood in this way, this radical future or godhead is not a time after the last mortal, but the time of the fourfold. In this, I am following Schürmann's work and in doing so, deliberately evading conventional readings of the godhead in Heidegger, for example, John D. Caputo, The Mystical Element in Heidegger's Thought (New York: Fordham University Press, 1986).

51 Martin Heidegger, Mindfulness [Besinnung], trans. Parvis Emad and Thomas Kalary (London: Continuum, 2006), 205.

${ }^{52}$ Schürmann, Heidegger on Being and Acting, 225.

${ }^{53}$ On this note, see the way Mudimbe remarkably articulates the arrival of God's speech in Africa and the creation of a more indigenous understanding of this speech in Africa in Mudimbe, Parables and Fables. See also the equally remarkable analysis of this tralatitious movement in Grant Farred, "Life, 'Life' and Death," in Grant Farred, Kasereka Kavwahirehi and Leonhard Praeg, Violence in/and the Great Lakes: The Thought of V-Y Mudimbe and Beyond (Pietermaritzburg: University of KwaZulu-Natal Press, 2014), 35-53.

${ }^{54}$ On the idea that language is war see Jean-Paul Martinon, After "Rwanda": In Search of a New Ethics (Amsterdam: Rodopi, 2013). See also on the theme of the Word of God and its repetition and translation: Andrew Benjamin, Translation, and the Nature of Philosophy: A New Theory of Words (London: Routledge, 1989), 151.

55 There is unfortunately no space here to deal with this enormous question: the establishment of an ethics no longer riveted to human actions alone, but in play with the other dimensions of the fourfold. On this topic, one would need to destabilize and decenter all understanding of ethics (starting from Levinas' radical ethics) and normative morality and free them from the centrality of our finitude and the pettiness of human actions. I hint at this, but more with an eye towards politics, right at the end of "Time Unshackled."

${ }^{56}$ As Schürmann rightly says, "The fourfold does not signify anything other than the constellationsno longer entities, not even of presence and absence-of the event in which the particular 'presences.' ...It signifies the ceaseless newness with which "the earth and the sky, the gods and the mortals determine 'the thing,' each thing." Schürmann, Heidegger on Being and Acting, 219.

${ }^{57}$ This does not mean that there is nothing outside of the thematization and rationalization of the fourfold; i.e. nothing that could be utterly unpredictable, dangerous, and even perhaps worrisome. The fourfold is also essentially vulnerable, open to danger and death. The whole 
section devoted to the 'Last God' in Heidegger's Beïtrage testifies to this, a section in which Heidegger precisely asks: "Why should thinking about the Godhead be a matter of calculation instead of an attempt at meditation on the danger of something strange and incalculable?" Although the gods depend on the event of being in order to sustain their divine nature, they do not therefore alter the fact that danger or opportunity structures the fourfold and mortals can still be called by an elsewhere." Martin Heidegger, Contributions to Philosophy (Of the Event), trans. Richard Rojcewicz and Daniela Vallega-Neu (Bloomington, Indiana University Press, 2012), 322.

58 There is no space to explore this topic properly here. Suffice to say that one of the most recent and forceful attempts to debunk the equation time = cogito comes obviously from the Speculative Realists and specifically, Quentin Meillassoux. The problem with Meillassoux's attempt to articulate time outside of all subjectivity (cogito) is that time ends up escaping all laws including the law of finitude that governs the subject that I am. As he says, "unreason becomes the attribute of [this] absolute time capable of destroying or creating any determinate entity without any reason for its creation or destruction." Quentin Meillassoux, Time Without Becoming (Rome: Mimesis International, 2014), 34. Meillassoux's absolute time then becomes equated with unreason or absolute contingency, without realizing that this absolute time can only really remain intelligible as Derrida and others have shown as always already absorbed in language, in Meillassoux's very own speech. The end result is that like correlationists before them, anti-correlationists effectively remain incapable of dealing with absolute ana-archy simply because they fail to see the mono-logical character of the reason (cogito) or mind that address it. For a comprehensive account of this movement, see Levi Bryant, Nick Srnicek and Graham Harman, eds., The Speculative Turn: Continental Materialism and Realism (Victoria: re.press, 2011). For a brave attempt to show that Meillassoux doesn't see the problems with his understanding of time, see Martin Hägglund, "Radical Atheist Materialism: A Critique of Meillassoux," in Levi Bryant, Nick Srnicek, and Graham Harman, eds., The Speculative Turn: Continental Materialism and Realism (Melbourne: re.press, 2011), 114-129.

59 As Schürmann rightly says, with the fourfold, human beings "find themselves, as it were, marginalized." Schürmann, Heidegger on Being and Acting, 211.

60 Ouattara, "Figures ethnologiques de la pensée de l'être," 90.

61 The following examples would need to be analyzed in detail in order to make this point more forcefully: Firstly, Derrida's "democracy to come" is exemplary of a philosophy overemphasizing the present without giving us a way out. See Jacques Derrida, "The Last of the Rogue States: The 'Democracy to Come,' Opening in Two Turns," trans. Pascale-Anne Brault and Michael Naas, in The South Atlantic Quarterly 103, No. 2/3 (Spring/Summer 2004): 323-341. Closer to us, the Accelerationists (See Robin Mackay and Armen Avanessian, eds., Accelerate: The Accelerationist Reader, Falmouth, Urbanomic, 2014) and their critics (for example, Benjamin Noys, Malign Velocity: Accelerationism and Capitalism, London, Zero Books, 2014) also give us a 'frenetic standstill' that offers no escape route out of global capitalism. There is also the work of Daniel Innerarity who calls for a future of calculation but no opening beyond this calculation, see Daniel Innerarity, The Future and Its Enemies: In Defense of Political Hope, trans. Sandra Kingery (Stanford: Stanford University Press, 2012). Finally, there are also the arguments against procreative or heteronormative futures in the field of queer theory, but no reflection on what lies beyond this eternal present. See, for example, Lee Edelman, No Future: Queer Theory and the Death Drive (Durham: Duke University Press, 2005).

62 The multiplication and deepening of futurities or gods would require to think the shift between ontological "dwelling" to ontical "inhabiting" and thus between commons to communities with 
specific gods. I hope to address this political issue in Jean-Paul Martinon and Adnan Madani, Visual Culture as World Forming (Berlin: Sternberg, 2017).

${ }^{63}$ In this last section, the second person pronoun will be used interchangeably with Africa. The occasional use of quotation marks is not intended to objectify the subject Africa, but as a reference to the person being addressed.

64 If, as Derrida has taught us, language is never mine, with the fourfold it becomes even more estranged, stubborn (earth), ethereal (sky), and godly (gods). On the fact that we never own language, see Jacques Derrida, Monolingualism of the Other or the Prosthesis of Origin, trans. Patrick Mensah (Stanford: Stanford University Press, 1998).

${ }^{65}$ Both in its undecidable sense (finite or infinite) and in the sense of the one within and without the other. These senses are here used within the context of mortals, but as will become evident, should be applied to the other three elements. For an analysis of this open word with regards to mortals alone, see Emmanuel Levinas, Of God Who Comes to Mind, trans. Bettina Bergo (Stanford: Stanford University Press, 1998), especially, 62-7.

${ }^{66}$ Like Derrida's arrivant, for example. See Jacques Derrida, Aporias Dying-Awaiting (One Another at) the "Limits of Truth," trans. Thomas Dutoit (Stanford: Stanford University Press, 1993), 74.

${ }^{67}$ For the idea that the earth is not a ground, see Martin Heidegger, Off The Beaten Track, trans. Julian Young and Kenneth Haynes (Cambridge: Cambridge University Press, 2002), 24-5.

${ }^{68}$ Mudimbe, The Idea of Africa, xv.

${ }^{69}$ On this theme, see Ouattara, Penser l'Afrique.

70 "The destinerrance of the envois, (sendings, missives, so to speak), is connected with a structure in which randomness and incalculability are essential." Jacques Derrida, "No Apocalypse, Not Now (Full Speed Ahead, Seven Missiles, Seven Missives)," trans. Catherine Porter and Philip Lewis, in Diacritics 14, no. 2 (Summer, 1984): 29.

71 This is Heidegger's word to describe the way the fourfold works together: "The gathered presence of the mirror-play of the world, joining in this way, is the ringing. In the ringing of the mirrorplay ring, the four nestle into their unifying presence, in which each one retains its own nature. So nestling, they join together, worlding, the world." Heidegger, "The Thing," in Poetry, Language, Thought, 178.

72 See Jacques Derrida, “The Law of Genre,” in Glyph 7, (1980): 202-32.

73 The expression "letting-be" [Gelassenheit] should be understood both as a way of letting ourselves be destined by the fourfold and opening ourselves to its mystery. "Letting-be" involves therefore no pre-de-termination of the fourfold. On the expression "letting-be" outside of any reference to the fourfold, see, for example, Martin Heidegger, Discourse on Thinking, trans. John M. Anderson and E. Hans Freund (New York: Harper \& Row, 1966), 54-7. For a commentary on this notion, see Bret W. Davis, Heidegger and the Will: On the Way to Gelassenheit (Evanston: Northwestern University Press, 2007).

74 "Hear" and not "see." The move from the ocular to the aural is crucial because it calls for a vibration and not for a visual objectification and appropriation (I see = I know). Heidegger talks, for example, of having an "ear for the never-ending resonance of the sound of the oldest words [i.e. the gods].” Heidegger, Mindfullness, 217. However, it is obviously Levinas who is the most acutely aware of the need to shift from seeing to hearing. See Levinas, Totality and Infinity, 126. For a commentary, see Derrida, "Violence and Metaphysics," 124-5. 